Swarthmore College

Works

Fall 10-1-2013

\title{
Love Against Substitution: John Milton, Aphra Behn, And The Political Theology Of Conjugal Narratives
}

\author{
Eric B. Song \\ Swarthmore College, esong1@swarthmore.edu
}

Follow this and additional works at: https://works.swarthmore.edu/fac-english-lit

Part of the English Language and Literature Commons

Let us know how access to these works benefits you

\section{Recommended Citation}

Eric B. Song. (2013). "Love Against Substitution: John Milton, Aphra Behn, And The Political Theology Of Conjugal Narratives". ELH. Volume 80, Issue 3. 681-714. DOI: 10.1353/elh.2013.0033

https://works.swarthmore.edu/fac-english-lit/180

This work is brought to you for free by Swarthmore College Libraries' Works. It has been accepted for inclusion in English Literature Faculty Works by an authorized administrator of Works. For more information, please contact myworks@swarthmore.edu. 


\title{
LOVE AGAINST SUBSTITUTION: JOHN MILTON, APHRA BEHN, AND THE POLITICAL THEOLOGY OF CONJUGAL NARRATIVES
}

\author{
BY ERIC B. SONG
}

When hereditary monarchy was put on trial in seventeenthcentury England, a fundamental question became supremely urgent: how should rulers be replaced upon death? Even before Charles II reclaimed his father's throne, the difficulty of enacting nonhereditary succession had been made evident when Richard Cromwell became Lord Protector after his father. After the Restoration, the Exclusion Crisis threatened to disrupt familial succession again by challenging the legitimacy of the future James II. By the end of the century, Jacobite uprisings continued to threaten the settlement that had been achieved by the Glorious Revolution. This essay begins with the logic of substitution - the notion that one person can effectively assume the place of another-and its diffuse but interrelated manifestations in seventeenth-century English writing. Hereditary monarchy relies doubly upon such logic: the monarch serves as God's deputy on earth, and his heir seamlessly replaces him at the moment of death. In the prefatory sonnet of Basilikon Doron, James VI of Scotland declares, "God giues not Kings the stile of Gods in vaine," before instructing Prince Henry to replace his father properly through both birthright and virtue. ${ }^{1}$

Hereditary monarchy also relies on marriage — both as literal practice and as metaphorical relation - to provide a vehicle of continuity. By regulating reproduction and the legitimacy of heirs, marriage reconciles what Ernst Kantorowicz calls "the King's sempiternity and the king's temporariness." ${ }^{2}$ As a metaphor, marriage anchors the political theology that James articulates. In 1603, James I declared before Parliament, "What God hath conjoined then, let no man separate. I am the husband, and all the whole island is my lawful wife." Kantorowicz argues that James's metaphor-which was "all but non-existent" in medieval theories of monarchy-adapts the corpus mysticum, the holy union between Christ, the groom and head, and the Church, his bride and body. ${ }^{4}$ Christian theology accommodates the synthesis of marriage's functional and spiritual roles. Genesis, after describing 
Adam's union with Eve, defines marriage around intergenerational substitution: "Therefore shall a man leave his father and his mother, and shall cleave unto his wife: and they shall be one flesh" (Gen. 2:24). ${ }^{5}$ Paul's epistle to the Ephesians reinterprets Genesis as foreshadowing an even greater truth:

So ought men to love their wives as their own bodies. He that loveth his wife loveth himself. For no man ever yet hated his own flesh; but nourisheth and cherisheth it, even as the Lord the church: for we are members of his body, of his flesh, and of his bones. For this cause shall a man leave his father and mother, and shall be joined unto his wife, and they two shall be one flesh. This is a great mystery: but I speak concerning Christ and the church. (Eph. 5:28-32)

Here Christ's sacrificial love becomes the new, spiritual meaning of marriage. This typological redefinition implicitly underwrites James's description of his kingdom as his bride; the king is aligned with the greatest bridegroom, Christ.

This essay argues that John Milton and Aphra Behn, writing from opposing positions, deploy a shared vocabulary of conjugal love that allows them to comment on the central political and theological controversies in late seventeenth-century England. ${ }^{6}$ Both Paradise Lost and Oroonoko define conjugal love as a rejection of all substitutes and an insistence on the beloved's irreplaceable status. Likewise, both Milton and Behn intensify the appeal of this kind of love precisely when it proves perilous or wrongheaded. By placing affective pressure on the belief that one person can take another's place, each of these conflicted narratives interrogates complex matters in political theology. Rather than making a case for Milton's direct influence upon Behn, however, this essay argues for a shared cultural logic whereby depictions of love can be understood to comment on interrelated economies of substitution-not only hereditary succession, but sacrificial atonement and communion as well.

In Milton's rigorously theological imagination, the question of marriage bears directly on matters of salvation. When Paul reinterprets Genesis to proclaim Christ's sacrificial love, he relates the meaning of marriage to a new set of questions concerning substitution. Explaining in what sense Christ dies in the place of sinners would eventually emerge as a central problem for Christian theology. Milton had manifested his ambivalence about Christ's crucifixion by publishing his early poem The Passion in unfinished form. Paradise Lost describes a world in which various forms of substitution-intergenerational and 
sacrificial—govern the creation and salvation of human beings, and yet such substitution is at odds with the sense that love requires an irreplaceable object. Paradise Lost and Paradise Regained raise questions about how to render the Father's satisfaction in the Son's death comprehensible to humans as an expression of love. Milton grapples with the artistic and theological problem of an aloof God, yet he shapes this problem into a support for his critique of hereditary monarchy. Milton situates salvation within a narrative of contested succession, but the demands of monarchical succession in heaven threaten to imperil love between God, his Son, and his creation. Similarly, for the Tory Behn, the Exclusion Crisis presented an occasion to depict in Oroonoko the social forces that render heroic love untenable. Richard Kroll reads Oroonoko as Behn's "desperate attempt between 10 and 29 June 1688 to warn James II that ... he risks suffering the same fate as his father." The definition of love against substitution helps to explain Behn's commentary on a bleak political situation. When Oroonoko suffers a fate that recalls Charles I's execution and its representation as a Christlike martyrdom, substitution and love are sundered in the royalist imagination. Because authority has been upended, debased forms of substitution can no longer sustain love as a stabilizing force. James II's legitimacy derived from birthright, but his familial history suggested that he might share the fate of his father, Charles. Reading Behn alongside her ideological enemy Milton produces a number of insights. The tension between love and substitution helps us make sense of Behn's difficult statements about religion in Oroonoko, including the protagonist's dismissal of Trinitarian doctrine and his rejection of Christianity. This context, in turn, clarifies the relationship between Behn's representation of slavery and her political convictions, which allows us to examine the latter without downplaying the importance of slavery in the narrative, as Kroll does. ${ }^{8}$ Slave labor represents the fungibility of persons in its most literal form. Without the linchpin of monarchy, diverse forms of substitution-succession, economic exchange, and sacrifice - cannot be bound up in loving harmony.

By the late seventeenth century, royalist ideology could no longer fully contain or claim for its own purposes the appeal of marriage and its affective bonds. The fact that both Charles I and James II married Catholic queens was a source of strife rather than stability. Conjugal love's partial unmooring from hereditary monarchy would have widespread consequences. This essay shows how this cultural shift gave rise to literary experiments such as those of Milton and Behn, which, in turn, helped to establish an ascendant literary sensibility concerning 
marriage. By attending to the political and theological significance of Milton's and Behn's conjugal narratives, this essay aims to show some of the complex ways in which historically precise commentary gets embedded in imaginative writing. Conversely, it also aims to show how cultural crises occasion new trends in literary representation. ${ }^{9}$ The concluding section suggests that the tension between love and substitution, more than a motif shared by Milton and Behn, may also serve as a trope to describe this momentous episode in literary history. When a breakdown in authority sunders substitution and love in Oroonoko, the female author finds the occasion for a hybrid prose form that draws upon epic, romance, and dramatic traditions to depict conjugal love. Born of this cultural amalgamation, Behn's literary progeny would go on to be reshaped by other hands into different forms, yet it has nevertheless retained its irreplaceable status for successive generations of readers.

Decades before the English Civil Wars and the execution of Charles I, writers already were depicting the tension between the literal and metaphorical senses of marriage under the system of hereditary monarchy. Kantorowicz does not mention how Shakespeare's Richard II (which he analyzes at length) anticipates and complicates James's conjugal image of kingship. On his way to the Tower of London, a defeated Richard proclaims himself

\section{Doubly divorc'd! Bad men, you violate}

A twofold marriage-'twixt my crown and me,

And then betwixt me and my married wife.-

Let me unkiss the oath 'twixt thee and me;

And yet not so, for with a kiss 'twas made. ${ }^{10}$

Shakespeare alters history to transform the child Isabella into an adult queen, with whom Richard shares a protracted and emotional farewell. The pathos of this scene suggests that Richard has, contrary to evidence, loved not only his wife but also his kingdom imagined as a metaphorical bride. Richard describes these two forms of marriage not as wholly discrete but as dual manifestations of a single phenomenon. He thereby presents himself as a Christlike bridegroom most effectively just as his literal and political wives are torn from him. The language of kissing reinforces Richard's suggestion that he has been betrayed by multiple Judases. 
Richard II underscores how royalist metaphors of marriage and reproduction function by suppressing and disavowing literal marriage. In act 1, the Duchess of Gloucester describes Edward III's sons as "seven vials of his sacred blood, / Or seven fair branches springing from one root." mothers in the process of succession, replacing them with the description of the English soil imagined as a maternal body. In the final act, however, the Duchess of York insists on the primacy of the literal family; motherhood is restored even at the expense of conjugal love. When York plans to turn in his son, Aumerle, for treason, the Duchess argues against it, pleading, "Wilt thou not hide the trespass of thine own? / Have we more sons? or are we like to have?"12 The historical Aumerle had a brother and a sister and was not, in fact, the son of the Duke's second wife. In Shakespeare's adaptation, the mother clings to a son who happens to be irreplaceable (although parental love can, strictly speaking, tolerate substitutes). Whereas Richard presents himself as a martyr upon having been betrayed, Bolingbroke becomes a "god on earth" by pardoning the Duchess's son. ${ }^{13}$

The image of the Christlike king reached its zenith precisely when monarchy was most beleaguered. The presentation of Charles I in Eikon Basilike would go on to hold sway over the public imagination for decades to come. During the Interregnum and the Restoration, Milton witnessed how a conviction that God had justly punished a wicked ruler ultimately proved insufficient to counter the claims of a royal Christology upon the hearts and memories of the English people. The view of the Christlike king held its affective sway over much of the country until, as Laura Lunger Knoppers puts it, "Charles I as crucified Christ gave way to Charles II as the resurrected Christ."14 The Tenure of Kings and Magistrates, an early work in Milton's polemical career, argues that "King and Subject are relatives, and relatives have no longer being than in the relation." 15 In Paradise Regained, by contrast, Satan declares, "The Son of God I also am, or was, / And if I was I am; relation stands." 16 Satan's position registers Milton's awareness, after the Restoration, that relation can outlast fierce attacks on its merit. Milton's later poetry thus must mount a more fundamental critique of the alignment of the ostensibly loving monarch with Christ.

In Paradise Lost, this critique manifests itself as a definition of love that defies the logic of substitution. In book 9, Eve speculates about the consequences of her recent transgression. To her, death remains somewhat mysterious, but the notion of being replaced by "another Eve" is a "death to think." ${ }^{17}$ Eve avoids this fate by convincing Adam 
to fall with her. Adam reasons, "Should God create another Eve, and I / Another rib afford, yet loss of thee / Would never from my heart" (PL, 9.911-13). Conjugal love is defined by the wife's desire never to be replaced and the husband's insistence on her irreplaceable status. Adam describes his choice as inevitable: "So forcible within my heart I feel / The bond of nature draw me to my own, / My own in thee, for what thou art is mine" (PL, 9.955-57). Adam loves unwisely. Insisting on free choice, Paradise Lost deems necessary evil to be the plea of tyrants and devils. Adam's reasoning proves especially incongruous in the work of a writer who supports divorce, remarriage, and perhaps even polygamy. ${ }^{18}$

For Milton, uxoriousness endangers not only obedience to God and spiritual devotion but also political life. In The Doctrine and Discipline of Divorce, Milton advises Parliament to see that, "[A]s a whole people is in proportion to an ill Government, so is one man to an ill marriage." 19 Later, in Eikonklastes, Milton casts aspersions on Charles's marriage to the Roman Catholic Henrietta Maria. In the same work he derides "effeminate and Uxorious Magistrates" who, "being themselves govern'd and overswaid at home under a Feminine usurpation, cannot but be farr short of spirit and autority without dores, to govern a whole Nation." ${ }^{20}$ Adam's inability to separate himself from fallen Eve manifests in the postlapsarian world as political cowardice and mismanagement.

Yet the affective bond of marriage and its uniquely proprietary nature serve to explain, although not to excuse, Adam's choice in a way that elicits sympathy. As The Doctrine and Discipline of Divorce explains, God implants in Adam a desire for conjugal fellowship, "properly call'd love," that "is stronger then death." Adam's impassioned sense of ownership by hailing wedded love as a "mysterious law, true source / Of human offspring, sole propriety, / In Paradise of all things common else" (PL, 4.750-52). "Sole propriety" grammatically modifies offspring, while the context dictates that love itself is property. Even in Eden, marriage exists to regulate ownership. Before the Fall, Adam's passion reinforces possession by precluding the wrongful transfer of love. As Eve recalls, Adam initially "claim[s]" and "seize[s]" her in an act of lawful coercion (PL, 4.487-89). As John Rogers argues, the conflict between the "inflexible aristocratic hierarchy" of marriage and an otherwise egalitarian paradise creates an untenable situation that helps to explain the Fall. ${ }^{22}$ Conjugal love makes such tensions visible. Genesis teaches that marriage exists for intergenerational substitution. In Milton's poetic rendering of this 
narrative, marriage may exist for substitution, but conjugal love itself can tolerate no substitutes.

Paradise Lost questions the political value of literal and metaphorical marriage by returning to marriage's divine foundations. Milton tests the synthesis of the literal definition of marriage in Genesis and its spiritual Pauline reinterpretation. "Adam spake like Adam the words of flesh and bones, the shell and rinde of matrimony," Tetrachordon teaches, "but God spake like God, of love and solace and meet help, the soul both of Adams words and of matrimony."23 Milton's divorce tract is fully informed by Pauline typology: whereas the first Adam refuses to forsake his wife when she has proven unworthy, the second Adam purifies an unworthy bride and fulfills the mystery of love. Yet Milton rarely invokes the biblical metaphor of the church as Christ's bride, and he does so not to express love but to describe incompatibility and the need for divorce. ${ }^{24}$ It is telling that Milton's late works devote so much attention to human marriage but remain relatively silent about Christ's marriage, a theme that had called for fuller exploration in such early writings as Lycidas and Epitaphium Damonis. Both the notion that love resists substitution and the tenets underlying Pauline theology connect Milton's reticence about Christ's marriage with his reluctance to write about another central matter, the Crucifixion. As William Kerrigan remarks, "Milton could never write with customary strength about the Sacrifice because he felt its intolerable illogic."25 This illogic concerns substitution: an innocent man dying in place of the guilty multitude, and a Father displacing his righteous anger onto his obedient Son.

Milton inherits a longstanding debate about how Christ dies in the place of sinners. In the late eleventh-century Cur Deus Homo, Anselm of Canterbury addresses the question, which he phrases as follows: "By what rationale does God forgive the sins of men?"26 He theorizes that sin is a debt of honor that all of creation owes to God. To satisfy for sin, Christ repays this debt through a life and death of perfect obedience. ${ }^{27}$ Christ thus confers upon believers a goodness they could not achieve on their own. In a magisterial history of Christian thought, Jaroslav Pelikan chronicles how the theologians of the Reformation would go on to adopt a soteriology based on Christ's ability to satisfy the Father. Pelikan remarks that although Luther's own account of imputed righteousness proved less than precise, "those who systematically formulated his teaching explained that in the Epistle to the Romans 'justify' is used in forensic fashion" to absolve an individual's guilt "on account of an alien righteousness, namely that of Christ." 28 
A penal doctrine of atonement assumes prominence. Calvin teaches that Christ was crucified so that "he might bear our curse which our sins deserved. ... He died, that by his death he might conquer death which was threatening us." ${ }^{29}$ According to this view, Paul's definition of conjugal love would be grounded, somewhat paradoxically, on a care for one's own body and on Christ's sacrifice of his own body on behalf of his undeserving future bride.

Milton had the opportunity to adopt heterodox alternatives to substitutionary sacrifice. In August 1650, he licensed for publication the Racovian Catechism, which teaches that Christ's death serves as an example of obedience and as proof that he will stand by the faithful in their tribulations. ${ }^{30}$ For Socinians, the Crucifixion was not essential for salvation but manifested Christ's patience in a fallen world. Such teachings may render divine love fully comprehensible. In Paradise Lost, however, the Father foresees human disobedience and insists on the necessity of penal atonement:

[Man] with his whole posterity must die,

Die he or justice must; unless for him

Some other able, and as willing, pay

The rigid satisfaction, death for death.

(PL, 3.209-12)

C. A. Patrides quotes these lines as exemplary of the cold voice of Milton's God to which many readers have objected. ${ }^{31}$ Patrides shows how Milton relies on a dominant account of salvation shared by Calvinists and Anglicans with Arminianist leanings. Yet Milton tests even the views articulated by God. Satan troubles the logic of substitution through his characteristic mode of dark parody. Upon encountering Adam and Eve, Satan devises a plan of displaced revenge. He imagines hell receiving the human pair and their future progeny and then declares, "Thank him who puts me loth to this revenge / On you who wrong me not for him who wronged" (PL, 4.386-87). When Satan voices his sense that God has wronged him, he most likely has in mind God's elevation of the Son to the status of viceregent and heir to the divine throne. Yet Satan unwittingly advances another, perhaps more damning accusation: God also operates through substitution, punishing one who "wrong[s him] not" in the place of those who have. Satan thus reveals that the feeling of satisfaction deriving from substitution may belong more properly to the realm of darker sentiments such as anger and revenge. 
God not only saves but also creates out of the principle of substitution. Satan rues the fact that God has created a new race to fill the room of the fallen angels. Raphael confirms this view by describing how God created the new world to "repair / That detriment" caused by the war in heaven (PL, 7.152-53). Adam and Eve learn that they owe their existence to the contingency of heavenly rebellion. In book 3 , the Son laments the possible loss of God's "creature late so loved" (PL, 3.151). Yet the Son's appeal must turn to the logic of displaced anger. Satan must not be allowed to achieve revenge by drawing God's latest creation to hell. The Son implores, "Or wilt thou thyself / Abolish thy creation, and unmake, / For him, what for thy glory thou hast made?" (PL, 3.162-64). While Milton's sense of conjugal love rejects the suitability of substitutes, creation motivated by substitution does not preclude parental love. In an earlier work, "On the Death of a Fair Infant Dying of a Cough," Milton advises a bereaved mother (likely his own sister) to take comfort in the prospect of a new child who will replace the dead infant. Yet the reader of Paradise Lost learns that all of humanity occupies the unfortunate position of the surrogate child. That everything serves to advance the Father's glory is a basic doctrine, but it is also one that creatures must struggle to accept as they seek divine love.

Milton's heterodox Christology further complicates the question of how substitutionary atonement can express divine love. Earlier in the century, John Donne had audaciously sought the possibility of reciprocal love between God and humans. After asking, "Wilt thou love God, as he thee!" Holy Sonnet 15 finds the basis of reciprocity in man's creation in God's image and God's incarnation as man. ${ }^{32}$ In Donne's Trinitarian worldview, the Father's love for humanity converges with the Son's love, which is at once divine and human. Such answers may not fully obtain in Paradise Lost. As John P. Rumrich argues, Milton's earliest readers recognized his antitrinitarian thought, and subsequent attempts to realign Milton's theology may reflect a misguided desire to render it more orthodox than it is..$^{33}$ When Paradise Lost yokes together the poet's nontrinitarian Christology and God's demand for penal atonement, love between God, the Son, and humanity becomes more difficult to conceptualize.

Rather than resolving these problems, Milton channels them toward his antimonarchical critique. The entire chronology of Paradise Lost begins with a conflict over divine succession. In book 3, the Son confirms himself as God's heir and thus justifies God by volunteering freely to die on behalf of humanity. The Father proclaims that the Son 
has "been found / By merit more than birthright Son of God" (PL, 3.308-10). In the case of divine succession, birthright and virtue should be perfectly coextensive. When Milton emphasizes the latter, however, he gives voice to his republican ideals by suggesting an ineluctable cleavage between birth and merit. ${ }^{34}$ The Son's meritorious choice proves that Satan was wrong to object to his coronation. Yet this proof emerges only as retroactive confirmation and as a consequence of the rebellion that raised the question in the first place. God's coronation of the Son (narrated by Raphael in book 5) leads Satan to rebel, and the Father reserves for the Son eventual victory over the rebels.

In this vertiginous sequence, the confluence of political and theological forms of substitution renders opaque love between God, the Son, and humanity. Anticipation of Christ's work of atonement should finally silence doubts about the Son's merit; the Son's free choice promises to unite filial obedience with love of God's latest creation. However, when Milton writes of the incarnate Son in Paradise Regained, Jesus does not strike the reader as particularly loving. "Perhaps what is most striking in Milton's presentation of Jesus," Richard Strier argues, "is what is missing from it. Totally absent is love as a topic or motive." ${ }^{\prime 35}$ For Strier, Jesus's indifference to saving sinners as an expression of love and his concern with demonstrating his merit together suggest Milton's valuation of classical magnanimity over Christian humility. In the context of my argument, the absence of love can be explained as the result of penal atonement put into the service of hereditary succession. The presentation of the Son as the embattled heir to God's throne underscores that the second Adam can find no intrinsic reason to accept his future bride, fallen humanity, as a unique object of love that supersedes a loving parent.

Paradise Lost explores the theological possibilities offered by nonconjugal models of love, including friendship and Neoplatonic ascent. Yet these models prove equally insufficient to reconcile the Father's satisfaction in the Son's death with a form of love comprehensible to humans. Their failure to do so anticipates the preeminence of conjugal love in the poem's conclusion and deepens Milton's critique of hereditary monarchy. In book 10, God commissions the Son to be "Man's friend, his mediator, his designed / Both ransom and redeemer voluntary" (PL, 10.60-61). Friendship offers a felicitous model of love. "Greater love hath no man than this," Christ teaches in the gospels, "that a man lay down his life for his friends" (John 15:13). Christ's sacrificial love represents both the highest form of friendship and the true meaning of marriage. As Thomas Luxon argues, however, 
Milton's writings manifest a failure to synthesize Protestant marriage and humanist notions of friendship as defined by classical texts such as Aristotle's Nicomachean Ethics and Cicero's De Amicitia. The forms of mutuality and sameness that Milton seeks in friendship clash with sex, procreation, and gender hierarchy, the seemingly inexorable features of marriage. ${ }^{36}$

Miltonic friendship also encounters a theological problem. The Son's friendly disposition cannot secure the full, spiritual meaning of conjugal love, because friendship amplifies the question of why Milton's God takes satisfaction in the death of his innocent Son. When the Son volunteers to die on humanity's behalf, he implores the Father, "Behold me then, me for him, life for life" (PL, 3.326). Commentators have long noted that the repetition of "me" recalls Nisus pleading for the life of his friend Euryalus in book 9 of the Aeneid. "Me, me, adsum qui feci, in me convertite ferrum," Nisus implores Volcens, asking the Rutulians to kill him rather than his younger friend. The fault, Nisus declares, belongs to himself alone: "mea fraus omnis, nihil iste nec ausus / nec potuit" (On me- on me-here am I who did the deed—on me turn your steel. . . . Mine is all the guilt; he neither dared nor could have done it). ${ }^{38}$ The claim may not be strictly true, but the poet's admiration for the two friends heightens the sense that, in killing Euryalus, Volcens commits an act of unnecessary cruelty. Such a comparison between Milton's Son and Nisus proves troubling, for, even when Christ successfully atones for humanity and perfects friendship, God's role may still be akin to that of the cruel Volcens. Milton's God deflects such a role by referring to the Son not only as man's friend but also as his ransom. The language may allude to Irenaeus's suggestion that Christ dies as a ransom payment to the devil or, perhaps, to death itself. This long outdated and unpopular view, however, cannot be sustained in any systematic way. ${ }^{39}$ As book 3 makes clear, Christ dies to satisfy the Father alone.

Milton's monist cosmology presents a more promising way of conceptualizing love between Creator and Creation. ${ }^{40}$ In book 5 of Paradise Lost, upon being asked if angels eat, Raphael depicts a world of digestive circulation: "[O]f elements / The grosser feeds the purer, earth the sea, / Earth and sea feed air, the air those fires / Ethereal" (PL, 5.415-18). Raphael later describes how "one almighty is, from whom / All things proceed, and up to him return, / If not depraved from good" (PL, 5.469-71). Conjoining monist vitalism with a Neoplatonic model of ascent, Raphael describes Creation striving toward perfection out of innate love for the Creator. As Barbara Lewalski points 
out, even the form of Raphael and Adam's colloquy recalls Plato's Symposium. ${ }^{41}$ God describes the Son's future work of atonement as potentially compatible with this brand of Neoplatonic monism. The Father describes the Son as "a second root" (PL, 3.288) for humans who will enjoy being "transplanted" (PL, 3.293) in him; this description anticipates Raphael's account of Creation as upward vegetal growth.

Conflicts arise, however, in Milton's gustatory imagination, where questions about monism and atonement converge with sacramentology. Raphael performs the progressive monism he describes by transubstantiating and purifying the food he eats. Milton's Protestantism, however, denies the possibility of transubstantiation in a fallen world. Richard C. McCoy describes how Milton's strident denial of "Real Presence" undercuts the forms of divine monarchy that persisted in Protestant England. ${ }^{42}$ If Milton's sacramentology proves compatible with his politics, it also conflicts with his monism. A complete exclusion of divine presence from the host may prove difficult to reconcile with Milton's monism, whereby, as Regina Mara Schwartz puts it, "the entire digesting universe is not only tending toward God; that universe also constitutes the body of God." 43 Yet such exclusion is crucial because it shields Christ from a profound violation of love as Neoplatonic ascent: if believers were literally to feed upon Christ's body, then a purer body would be nourishing ones grosser than itself. Yet penal atonement demands precisely this intolerable inversion. That God desires a pure Son to die on behalf of gross humanity remains incompatible with the account of organic love between Creator and Creation offered by Raphael.

In Paradise Regained, Milton's Jesus struggles to understand the contradictions he embodies. Schwartz argues that the climactic temple scene of Paradise Regained returns to a nonpenal model of atonement that explores alternatives to substitutionary sacrifice. ${ }^{44}$ Jesus seems to achieve salvation not in death but in faithful obedience. The poet himself seems to invite such a reading, which preserves a continuity of love between God, Son, and humanity. The opening of the first book declares that the Son raises an Eden in the wilderness rather than at Golgotha, displacing the Crucifixion with steadfastness against temptation. Yet the poet's and the Son's desire to appease the Father through obedience nonetheless encounters a limit in the "rigid satisfaction, death for death" that God has already demanded in Paradise Lost. ${ }^{45}$ Thus, just as in earlier poems such as "On Circumcision" and the unfinished "Passion," Milton's Jesus must await an illogical fate. Despite serving as a fitting sequel to Paradise Lost, Paradise Regained 
famously ends in suspension. Whereas, in the gospels, a dying Jesus gives his mother to a new son, Milton's Jesus postpones his final exit from his mother's house.

Love between the Father, the Son, and humanity proves difficult to imagine, but maternal care abounds in Mary. ${ }^{46}$ As we have seen, for Milton, the tension between love and substitution manifests itself as a tension between the definition of marriage in Genesis and its Christian reinterpretation. Jesus atones for humanity as the second Adam, and Milton's epics also invoke Mary as the second Eve. Such descriptions underscore the curious fact that the second Eve is mother to the second Adam; maternal love overshadows conjugal love. Typological fulfillment thus inverts the account of marriage as a replacement for the original experience of parental love. Jesus must eventually leave his mother's side to become a bridegroom, but Mary arrests this cycle of substitution and restores the beleaguered role that mothers play in succession.

Mary teaches the Son that his "father is the eternal King" (PR, 1.236) and that he will "be great and sit on David's throne" (PR, 1.240). The questions that arise concerning the relationship between divine and human thrones direct us to the poem's central question: in what sense is Jesus both a divine Son and human? ${ }^{47}$ Jesus rejects all methods of obtaining an earthly throne, preferring instead the spiritual rule that prepares him for divine kingship. Jesus has learned from his study of "prophetic writ" to anticipate a reign that "shall never end" (PR, 3.184-85). Yet Jesus is heir to a throne that may never be vacated. In Paradise Lost, the Father declares that the Son should "reign for ever" (PL , 3.318) but envisions him laying down the scepter, for "God shall be all in all" (PL, 3.341). When the Father commands, "Adore the Son, and honour him as me," he does not specify whether he will mysteriously abdicate even while becoming all in all, or whether the Son can assume an eternal reign only in the subjunctive (PL, 3.343). In the final book of Paradise Regained, angels exalt Jesus as "Son of the Most High, heir of both worlds" (PR, 4.633). The retreat to Mary's house confirms, however, that the status of being God's heir is doubly paradoxical: it anticipates a substitution that has no necessary reason to occur but nonetheless displaces onto the heir a punishment he does not deserve.

This vexed familial narrative helps us account for the relationship between Paradise Regained and one of its main biblical sources, the Book of Job. ${ }^{48}$ Questions of substitution persist to trouble common typological interpretations that teach God's love for the Christian 
reader. In the final chapter of Job, God rewards his longsuffering hero by restoring his family and doubling his lost possessions. It is unclear, however, whether God provides Job new children or if the children who had been sold into slavery have returned. "He had also seven sons and three daughters," the text tells us (Job 42:13). If these are new children, the happy conclusion would demand that Job be satisfied with replacements for the children he has lost. George Abbot's 1640 paraphrase of Job ignores this possibility: "And whereas all his children you heard were taken from him, he had them restored him againe, even their full number." 49 Abbot does not explain why Job’s three daughters receive names after their restoration-or whether they receive new names or had previously been nameless. What the text does tell us is that these daughters are exceptionally beautiful and that "their father gave them inheritance among their brethren" (Job 42:15). Appreciation of beauty stands in for fatherly love, and it leads to what Abbot calls an "extraordinary president [precedent]" whereby Job's daughters "shared proportionably with their brethren ... and were coheires with them in his estate." ${ }^{\text {" Ho }}$ However, the final chapter of Job conceals more vital information. Although the final verse describes how Job lived long enough to see four generations of his sons' offspring, whether his daughters marry or reproduce remains unspoken. The destinies of Jemima, Kezia, and Kerenhappuch, and of their familial property, remain mysterious.

The anomalous and potentially short-lived entry of Job's daughters into patrimony harks back to the sacrificial economy of Job's opening chapter. To each of Job's seven sons is appointed a daily feast, and his daughters are also invited to join. These celebrations serve as opportunities to take active measures against the possibility of sin. Job thus "offered burnt offerings according to the number of them all: for Job said, It may be that my sons have sinned, and cursed God in their hearts" (Job 1:5). Here, too, questions arise concerning the status of Job's daughters. Sacrifice demands an exact transaction of an offering for each child; however, while the phrase "the number of them all" might be understood to encompass all ten children, Job’s reasoning suggests that the sacrifice atones only for his sons. From beginning to end, Job's daughters play a role in the affective bonds of the family without being wholly integrated into the substitutive economies of property and atonement.

From a Christian perspective, this narrative requires typological fulfillment to become a lesson about God's love. Calvin's sermons on Job instruct Christians to learn from Job's sacrifice and to cleanse 
themselves through faith in Christ. ${ }^{51}$ Yet Job foreshadows not only the future Christian but also Christ himself. In the last chapter, Job prays on behalf of his friends; this gives Calvin occasion to emphasize Job's role as a type of Christ the intercessor. In another twist, Job's role is reinterpreted as anticipating the Christian's status as a child of God. Calvin reads "the bewtie of Jobs daughters," as well as his wealth and long life, as imperfect experiences of divine favor. For Christians, "the shadows and figures are past: wee have the bodie of them in our Lorde Iesus Christ: therefore wee must be contented with whatsoever God giveth us." Christians take comfort in "a more large declaration of Gods fatherly loue towards" them. ${ }^{52}$ The beauty of Job's daughters is rendered obsolete as a sign of divine favor both because it is superficial and because God's paternal love supersedes Job's.

In Paradise Regained, Jesus faces the challenge of fulfilling familial relations and rendering them as mere signs for the higher love between God and his children. Jesus must not only be the one greater Job, but also the better version of the sacrifice that Job offers for his sons. Only then can Job's superficial appreciation of his beautiful daughters be surpassed by the Father's love for his formerly reprobate children. In Paradise Regained, God proudly compares the Son to Job, proclaiming to Gabriel that he has chosen the "perfect man, by merit called my Son, / To earn salvation for the sons of men" (PR, 1.166-67). Yet the Son has proven his merit by volunteering to die; even after resisting temptation in the wilderness, Jesus must await the Joblike paradox of being punished in order to be the righteous Son. He finds temporary reprieve by following Job's suggestion. "Naked came I out of my mother's womb, and naked shall I return thither," Job reasons when he first experiences senseless tribulation (Job 1:21). Job has left his mother for a wicked wife, who tells him to "curse God, and die" (Job 2:9). Suffering even greater despair, Job later exclaims, "Why died I not from the womb?" (Job 3:11). Remaining within the maternal body —imagined as the place of origins and of ends — would allow Job to escape the redemptive but painful cycle of loss, restoration, and substitution. Clinging to the maternal body is an untenable, regressive act, but it is the only loving option available to Milton's Jesus. The Son awaits the unmerited punishment he will suffer on behalf of his future bride as a man by his mother's side. 
In Oroonoko, Behn's royalist sensibility coincides with Milton's depiction of conjugal love as an insistence upon an irreplaceable object. Behn's hero possesses an anomalous sense of love that sets the terms of his downfall. Even before becoming a slave, Oroonoko's innate nobility leads him to view people as fungible. He offers Imoinda 150 slaves as recompense for her father, who died to save Oroonoko in war. Implicit in his offering is an exchange rate: the life of the general is worth those of 150 slaves. Even though Oroonoko's love emerges from this economy of substitution, his nobility manifests itself as an aberrant refusal of substitutes in love: "[C]ontrary to the Custom of his Country, he made [Imoinda] Vows, she shou'd be the only woman he wou'd possess while he liv'd." ${ }^{53}$ In both Coramantien and Surinam, however, debased authority fails to harness this unique form of conjugal love for the perpetuation of dynastic kingship and social harmony.

Unlike Milton, Behn did not stake much of her personal happiness and public reputation on the spiritual merits of conjugal love. Yet she writes of love as both a problem and a vehicle for her royalist values. The Forc'd Marriage; Or, The Jealous Bridegroom, Behn's first play, unleashes and then contains love's disruptive potential. For valor in war, Alcander receives from the king the title of the old General Orgulius and the hand of Orgulius's daughter Erminia. Unbeknownst to Alcander and the king, Erminia has secretly promised to marry Prince Phillander. This precontract does not prevent the forced marriage of the title from taking place. Erminia, however, delays consummating her marriage, and Alcander grows jealous of her interactions with Prince Phillander. Alcander eventually attempts to murder his wife. His passion turns politically treacherous as he refuses to subordinate his jealousy to political subservience. As the prince's friend Alcippus remarks, "Love is a surly and a lawless Divel." but only because Erminia survives Alcander's attempt to murder her and Princess Galatea loves Alcander despite his actions. Galatea pleads with the king to have mercy on Alcippus by appealing to conjugal love's role in intergenerational substitution: "If e're my Mother, Sir, were dear to you / . . . / Dispence your mercies, and preserve this Copy, / Which else must perish with th'Original." 55

By the end of the play, the king aligns marriage and love properly. As Janet Todd notes, however, the play's politics remains ambivalent. The king's initial decree is what generates the play's central problems, and even at the conclusion, the "kingdom in which the proud 
Erminia and Alcippus exist can have no very great hope of peace." ${ }^{.56}$ Todd speculates that Behn depicts two royals marrying commoners in order to compliment the Duke of York's contentious choice to woo and marry Anne Hyde. In the years between The Forc'd Marriage and Oroonoko, James's familial and conjugal affairs became intertwined with the controversies that would lead to his downfall. James had repeatedly refused his mother's attempts to sway him toward Roman Catholicism, and yet he followed his first wife's decision to convert in the months either immediately before or after his mother's death. After the death of Anne Hyde, who had produced no surviving male heir, James would go on to aggravate anti-Catholic fears by marrying Mary of Modena in 1671.

Following the Rye House Plot and the Monmouth Rebellion, James's accession to the throne in 1685 was somewhat anticlimactic. Yet Behn's "Pindarick Poem on the Coronation" registers in both poetic and theological registers the dangers posed by James's remarriage. The poem exalts both James and Mary but invokes the latter repeatedly as Laura, thus turning the new queen into the potentially recalcitrant object of the king's Petrarchan desires. Behn celebrates the fulfillment of the king's desires by modeling her Pindaric upon the epithalamion. "Awake, Oh Royal Sir! Oh Queen, ador'd, awake!" Behn pleads. ${ }^{57}$ Poetry plays a role in turning the love between king and queen into the occasion of love between monarchs and subjects. Behn banishes from this celebration those who would gaze upon the "Goddess of the Day" with envy and "raging Malice even to Madness." 58 In the latter half of the poem, Behn's apotheosis of the king reaches its climax. After describing the queen, somewhat dangerously, as "the fair INCHANTRESS," Behn compares her presence to the "wonder that the Prophet did unfold, / When Heav'n in Revelation he survey'd / And the Bright Woman did behold." ${ }^{59}$ Here Behn refers to the twelfth chapter of Revelation, which describes a "woman clothed with the sun" who is persecuted by the dragon as she gives birth to "a man child, who was to rule all nations with a rod of iron" (Rev. 12:1-5). Roman Catholic exegesis identifies this woman as the Virgin Mary. ${ }^{60}$ Mary of Modena would thus, according to her own religion, be compared to her biblical namesake. Yet Protestant readings often reinterpret the woman as Christ's bride, producing curious circularities. The Geneva Bible, for example, glosses the woman's birth pangs as the church personified, who with "a most fervent desire longed [that] Christ should be borne, \& that the faithful might be regenerate by his power." ${ }^{\prime 61}$ Behn optimistically splits the difference between Catholic and Protestant 
views, hailing Mary both as the future mother of a godlike heir and as the bride of a godlike king. Still, the allusion to a contested passage in Revelations implicitly acknowledges the presence of another woman of the apocalypse, the whore of Babylon, a ubiquitous symbol of popery.

From Behn's Tory perspective, the political situation in England had grown quite dire by 1688 . The publication of Oroonoko coincided roughly with the birth of James Francis Edward Stuart in June of that year; Behn advertised the imminent publication of her story at the end of her poem celebrating the prince's birth. ${ }^{62}$ The birth of this heir helped to precipitate the coup six months later, and the legitimacy of James II's son would remain a signal political question for decades to come. Oroonoko responds to developing upheavals in part by returning to memories of 1649. "I have often seen and convers'd with this great Man," the narrator tells us of the protagonist, who confirms his nobility by recounting how "he had heard of the late Civil Wars in England, and the deplorable Death of our great Monarch; and wou'd discourse of it with all the Sense, and Abhorrence of the Injustice imaginable" $(O, 13)$. Oroonoko himself meets the same abhorrent fate, and his quiescence at death marks him as a Caroline martyr: "[H]e gave up the Ghost, without a Groan, or a Reproach" $(O, 64)$. Unlike Charles, however, Oroonoko dies as the victim of a sacrifice whose religious logic he has rejected. How Oroonoko's grisly death can achieve redemption-or what political lesson Behn's narrative can impart-remains opaque.

Oroonoko does not articulate a clear position on either Catholicism or toleration - the central religious crises of the 1680s — but Behn's depiction of Christianity nonetheless remains striking. Long before Oroonoko deems the Trinity a riddle that "woul'd turn his Brain to conceive," the narrator deems religion inimical to the inhabitants of Surinam $(O, 41)$. The reader learns later that violence and religious charlatanism are indigenous to the supposedly Edenic realm, yet the shortcomings of Christians recur throughout the narrative. Anita Pacheco shows how Behn creates an opposition "between a religion that offers a supernatural sanction for morality and a secular ethic that locates morality in the relationship between a man and his fellow men." ${ }^{\prime 3}$ The political and theological implications of defining love against substitution help to account for the tensions between royalism and Christianity. Whereas Behn's "Pindarick" had celebrated the king and queen's public love by alluding to the birth of the Son of God and to his marriage to the personified church, Oroonoko ends with the royal slave's crucifixion. 
In Milton's writings, defining love against substitution generates soteriological problems that unsettle the metaphors of royal Christology. Behn, by contrast, suggests that a lack of proper monarchical authority threatens to turn a powerful scene of sacrifice into a travesty. The uneasy religious sentiment of Oroonoko confirms that Oroonoko's death is a debauched or farcical version of royal martyrdom, which, in turn, raises questions about the efficacy of the monarch's Christlike image in the late seventeenth century. Describing recollections of Charles I as a martyr, Lois Potter observes, "Idealization of Charles I is an obvious way of rebuking Charles II, but even praise of the late king is sometimes a two-edged sword" because it could turn the son into a comic actor reprising his father's genuinely tragic role. ${ }^{64}$ The memory of Charles I would prove even more problematic for James. Laura Lunger Knoppers details how the Jacobite strategy of appealing to the memory of Charles I as royal martyr could only win support "at the cost of effecting any kind of real change." 65 James's predicament, then, is that he is at once not his father and too much a copy of him. Both Charles II and James II married foreign, Catholic princesses as their father had done before them, but only the latter son openly converted. James II decisively fulfilled the anti-Catholic suspicions that had plagued his father.

In exploring the religious and political dimensions of substitution in terms reflective of Milton's literary vocabulary, Behn fosters a more explicit awareness of human fungibility. Oroonoko's love for Imoinda originates in an act of sacrifice:

[The general] was kill'd with an Arrow in his Eye, which the Prince Oroonoko ... very narrowly avoided; nor had he, if the General, who saw the Arrow shot, and perceiving it aim'd at the Prince, had not bow'd his Head between, on purpose to receive it in his own Body rather than it shou'd touch that of the Prince, and so saved him. $(O, 12)$

The focus on the general's eye suggests, at the same stroke, willing, voluntary sacrifice and an exact, eye-for-an-eye substitution. Military valor combines with martyrdom in the bowing of the general's head. Oroonoko visits Imoinda to make amends with a gift of slaves, but he ultimately offers himself instead; thus, Imoinda loses a father but gains a husband. As we have seen, however, Oroonoko's love for Imoinda transcends its cultural context as a monogamous rejection of substitutes. Their noble love takes part in a cultural economy of human exchangeability but also defines its limit. 
However, the corruption of monarchical power in Coramantien and the absence of proper authority together force Oroonoko and Imoinda into the role of slaves-a position that reveals human fungibility in its most intolerable form. The prospect of giving birth to an heir in the condition of slavery torments the royal couple: a pregnant Imoinda reasons that "if it were so hard to gain the Liberty of Two, 'twou'd be more difficult to get that for Three" $(O, 51)$. Such fears, in turn, lead Oroonoko to break his word and lead an uprising. As royal slaves, Oroonoko and Imoinda embody economic exchange run afoul. Recent scholarship has shown how seventeenth-century writings responded to economic developments that resisted state control. ${ }^{66}$ Kroll's expansive study of Restoration tragicomedy reads the genre as a site of various forms of circulation-foreign trade, physiological function, and the transmission of print materials. Tragicomedy, according to Kroll, allowed royalists to embed complex advice into their plays: the genre's mixed plots accommodate representations of a mixed monarchy, and the trope of circulation allows disparate, even opposed, ideas and elements to coexist without any simple unifying force. ${ }^{67}$

In Oroonoko, the circulation of the enslaved hero and heroine connects the multiple plots. The sale and purchase of these royal slaves intersect with religious concerns to show how substitution without proper rule fails to secure genuine meaning. Debased substitution explains the lack of authority in Surinam. When Byam plots to exact cruel revenge upon Oroonoko, Trefry tries to prevent him from doing so by making a case that the servants of Parham represent Willoughby (who himself derives authority from the king) directly, bypassing Byam's twice-removed authority. Trefy argues that Byam's men "ought no more to touch the Servants of the Lord [Willoughby] (who there represented the King's Person) than they cou'd those about the King himself' $(O$, 59). Geographical distance between throne and colony creates a split between sovereignty and management, but Trefry attempts to conjoin the two. The language of touching suggests that Trefry appeals to the sanctity of the king's body so that potent monarchical presence might be infused even in Willoughby's servants. Yet Trefry's speech ultimately does little more than underscore the infelicitous connections between the fates of Oroonoko and Charles I by likening the plantation to Whitehall, the site of the king's execution in 1649.

Lord Willoughby will never return to restore order because he has drowned in the expanse between motherland and colony. Yet the anticipation of his arrival makes room for the dilation of the romance plot, as the narrator and her crew accompany Oroonoko on a series of 
adventures to distract him. In one of these excursions, an electric eel almost kills Oroonoko. After Oroonoko's rescue, the narrator writes, "[W]e had the Eel at Supper; which was a quarter of an Ell about, and most delicate Meat; and was of the more Value, since it cost so Dear, as almost the Life of so gallant a Man" $(O, 47)$. In Milton's writings, the tensions between love and atonement can be expressed as sacramental problems with political implications. In Oroonoko, the eel episode deploys the language of human fungibility to describe a comical but transgressive parody of the Eucharist. The added value of the eel is almost commensurate with Oroonoko's life. Eating the eel's "delicate Meat" will be as close as these characters get to eating the flesh of Oroonoko, but this secular communion will result in only perverse, nearly cannibalistic delight. If Oroonoko himself eats the eel, sign and signified are linked in an economy of vacuous circularity.

Such circularity becomes more explicit at Oroonoko's death, unsettling the link between the suffering bodies of Christ and king. The only agency that remains for Oroonoko is the ability to ironize his staged execution by smoking a pipe. Stephanie Athey and Daniel Cooper Alarcón remind us that "Orinoco" is the name of a strain of tobacco, and that "the arresting image of Oroonoko taking tobacco while his own body burns makes literal the analogy between enslaved slave trader and the commodity for which he is named." 68 At the moment when Oroonoko should evoke the memories of a wrongfully executed king-who is modeled upon the longsuffering Christ-Oroonoko reminds observers that only the economy of fungible goods truly operates at his death.

However, Oroonoko has been the agent as well as the victim of substitution run afoul. Within Imoinda's womb, the economy of the slave trade collides with that of royal succession, which should render human substitution compatible with innate nobility. ${ }^{69}$ The relationship between love and substitution in Oroonoko becomes graphically clear in Imoinda's sacrifice. In The Forc'd Marriage, Behn had borrowed heavily from Othello's depiction of a husband's unbridled jealousy. Yet Behn's tragicomedy ends happily by borrowing a familiar device of Shakespearean comedy, the mock resurrection. At the end of Measure for Measure, the Duke declares to Mariana that her newly betrothed husband will be executed: "An Angelo for Claudio, death for death!"70 The Duke commands Mariana to buy a better husband, but she pleads, "I crave no other, nor no better man." 11 That Claudio has not been executed saves Angelo from the penal economy of death for death. Oroonoko, by contrast, hews more closely to Othello's tragic conflation 
of love and revenge. Iago declares that he loves Desdemona not out of "absolute lust" but "partly led to diet [his] revenge." " Iago deploys his erotic jealousy to fuel a desire for vengeance, which will thus seek to exact "wife for wife." 73 Echoing "life for life," Iago's formula aligns him with a devilish satisfaction in substitution as a recompense for a perceived wrong. Once Othello has succumbed to Iago's unholy desire for retribution, he can describe killing Desdemona as an act of sacrifice rather than of murder. After Othello realizes his folly, his last resort is to be both the agent and victim of another act of sacrifice. In the First Folio, Othello calls himself a "base Iudean" (as opposed to "Indian" in the 1622 Quarto) who "threw a pearl away / Richer than all his tribe," potentially aligning the murder of Desdemona to the betrayal of Jesus and his self sacrifice to Judas Iscariot's suicide. ${ }^{74}$

Behn learns from Othello a way to add theological resonances to a narrative of love, substitution, and revenge, but she also deviates from Shakespeare in meaningful ways. Oroonoko does not kill his wife because he has been deluded by a social inferior but because the erosion of monarchical order leads to the conflation of human fungibility and royal succession. Excessive violence is the only way that Oroonoko can express his love. Imoinda consents to her own sacrifice, "for Wives have a respect for their Husbands equal to what any other People pay a Deity" $(O, 60)$. At this point, however, the narrative produces a famously discordant effect. Oroonoko is described as "first, cutting her Throat, and then severing her yet Smiling Face from that Delicate Body, pregnant as it was with Fruits of tend'rest Love" $(O$, 61). The narrator's protestations merely heighten the reader's inability to accept fully this act of love. The narrator herself has access to this literally obscene moment only through a "Relation of it . . afterwards" $(O, 61)$. Unlike Othello, Oroonoko has not committed his murderous act of loving too well in error. Yet he, too, registers that his act is a travesty by describing it as an attempt to obtain revenge and glory. Oroonoko discovers that a sacrifice of love has no affective power to purchase.

In Oroonoko, the hero's life is preserved only so that he can become the target of revenge in a ceremony that underscores how debased Christian society has become in Surinam. Othello retains enough strength to kill himself, occupying both the roles of Christian Venetian and circumcised enemy of Venetians. Oroonoko does not feel a divided religious identity, but suicide offers a way to escape his dual identity as a noble prince and as a slave ironically named Caesar. Yet Oroonoko refuses to kill himself until he has avenged his wrongs to his satisfaction: 
"No, I wou'd not kill my self, even after a Whipping, but will be content to live with that Infamy . . . till I have compleated my Revenge; and then you shall see that Oroonoko scorns to live with the Indignity that was put on Caesar" $(O, 58)$. When he finds himself too weak to exact revenge, however, Oroonoko turns his knife against himself; he "cut[s] a piece of Flesh from his own Throat, and thr[ows] it" at the English colonists $(O, 62-63)$. By mimicking the actions of the Indian warriors he had witnessed earlier, Oroonoko tries to demonstrate his unchristian identity through his final act. Even this bit of agency is denied him. Oroonoko's loyal friend Tuscan saves him out of love, but Byam and his wicked men wrest control of Oroonoko's life so that they can dictate the meaning of his death. After being sacrificed, Oroonoko's body is quartered: "They cut Caesar in Quarters, and sent them to several of the chief Plantations. One quarter was sent to Colonel Martin, who refus'd it; and swore, he had rather see the Quarters of Banister, and the Governor himself, than those of Caesar" (O, 64-65). Oroonoko undergoes the punishment meted out to traitors, underscoring the contradiction of his status as both slave and prince. ${ }^{75}$

Oroonoko's quartering amplifies the political and theological commentary of Behn's conjugal narrative. As a critique of slavery, this moment condemns only the grossest excess, for the virtuous slaveowner Colonel Martin declares that "he cou'd govern his Negroes without . . . frightful Spectacles of a mangl'd King" $(O, 65)$. Yet this episode speaks far more expansively to the clash between monarchical power and conjugal bonds. Oroonoko's fate echoes the story of the Levite concubine in Gibeah. The Book of Judges recounts how a Levite takes his new concubine into Benjamite territory. In Gibeah, "certain sons of Belial" seek to sleep with the Levite; his host offers instead both his own maiden daughter and the Levite's concubine (Judg. 19:22). The next morning, the Levite finds his concubine defiled and "fallen down at the door of the house" (Judg. 19:27). Once home, the Levite kills his concubine, divides her body into twelve pieces, and sends them to "all the coasts of Israel" (Judg. 19:29). Israel responds by waging a divinely sanctioned war against the Benjamites, killing 25,000 and setting fire to their cities.

In the 1680s, Judges served as a focal point of heated political debate. The story of the Levite and his concubine occurs in "those days, when there was no king in Israel" (Judg. 19:1) and thus takes part in the leitmotif of the entire book: "In those days there was no king in Israel: every man did that which was right in his own eyes" (Judg. 21:25). John Maxwell's Sacro-sancta Regum Majestas, composed in the 1640s but 
reprinted in the 1680s, includes the story of Gibeah among examples of how "Religion is defaced, Justice is abused, Honesty and Civil moral Conversation is shaken off; Dishonesty, Impiety, Uncleanness are avowed" in the absence of monarchical authority. ${ }^{76}$ Nathan Bisbie, who would go on to refuse the oath of allegiance to William and Mary, cites Judges 19 and goes on to enumerate the consequences of anarchy: "Sacriledge and Theft follow; then marches Whoredom, Rape, Adultery; after these, Murder, Bloodshed, Civil War." ${ }^{\text {77 }}$ By contrast, William Denton, who had served as court physician to Charles I and dedicated a treatise to Charles II, uses the same episode in Judges to argue for the propriety of the 1688 Revolution. God encourages Israel to bring just punishment "on a whole Tribe, which had so offended," a victory that sets a precedent for "Christian Men, to maintain and defend the true Christian Religion in it's purity against all opposers."

The parallels and discrepancies between this biblical narrative and the end of Oroonoko are illuminating. Oroonoko preempts the violation of his beloved wife by killing her, yet this means that he himself will suffer the fate of the concubine. This reversal suggests his lack of agency: only his victimization can make him a potential catalyst for action against injustice. Behn's narrative cannot end with any practical exhortation but only with a grim warning. Yet Colonel Martin's refusal of Oroonoko's remains suggests that even the image of a mangled king can no longer spur action. Indeed, it may not be clear what viable modes of action remain. Merely awaiting the king's grim fate is not a satisfying option and, as arguments such as Denton's suggest, decrying internal turmoil as the result of insubordination cannot silence opposing claims that civil war is sanctioned by God as a righteous response to debasement.

Oroonoko's warning thus appeals not only to the Gibeah episode in Judges - in which the people cooperate with God to right an injustice-but to the older parallel narrative of Sodom and Gomorrah's destruction. Lot successfully defends his family from the lust of the residents at Sodom and flees as God himself brings destruction on the wicked city. The spectacle of injustice may not induce political action on the part of the people, but God himself strikes down wicked states. Surinam has suffered such a fate by being lost to the Dutch. Behn's mournful description of the once paradisal Surinam conjoins the Gibeah and Sodom stories. The Dutch have treated the Indians "not so civilly as the English; so that they cut in pieces all they cou'd take, getting into Houses, and hanging up the Mother, and all her Children about her; and cut a Footman, I left behind me, all in Joynts, 
and nail'd him to Trees" $(O, 47)$. Through the violence of the Indians, Behn expresses her desire for English action against (or, failing that, divine judgment upon) the Dutch. Yet developments in England after the 1667 surrender of Surinam have shown that the warnings of Sodom or Gibeah apply at home rather than abroad..$^{79}$ Whether England will succumb to civil war or to divine judgment remains unclear, but no way of avoiding one of these tragic endings presents itself.

Milton and Behn pit conjugal love against substitution for opposed ends. In Paradise Lost and Paradise Regained, Milton channels his commitment to companionate marriage into a critique of hereditary monarchy. Behn, by contrast, laments the inability of the Stuart monarchy to harness for its own purposes the affective appeal of marriage. Both writers, however, participate in a momentous cultural shift: as conjugal love becomes increasingly independent from the auspices of monarchical power, it falls into the domain of individual subjects. This shift would eventually find expression in a new form of writing. Influential accounts of literary history have pointed to Paradise Lost as a turning point in the rise of the novel and its choice of bourgeois rather than aristocratic subject. Ian Watt refers to Milton's poem as "the greatest and indeed the only epic of married life," one that articulates a "Puritan conception of marriage and sexual relations [that] generally became the accepted code of Anglo-Saxon society." 80 Samuel Richardson, according to Watt's genealogy, inherits this code and ties it to the novel form. Subsequent studies of the novel's origins, notably Michael McKeon's, have examined the uses and deficiencies of archetypal or evolutionary and teleological modes of historical inquiry. ${ }^{81}$

Conjugal love serves not only as a motif around which this episode of literary history turns, but also as a metaphorical model for an economy of surrogates and proxies giving rise to singular objects of affection. Relation stands not only between Milton and Behn but also between disparate literary genres and styles. As a model for literary history, linear succession is the product of a more diffuse pattern of hybridity, competition, supersession, and reemergence. Oroonoko uses the language of love and substitution to meditate upon its own status as a literary production. On the cusp of another English coup, Behn's conjugal narrative can offer no programmatic advice. James II would not forsake his Catholicism, nor could he abandon (let alone sacrifice) 
his Catholic wife and heir. However, the narrator concludes with cautious optimism - if not about English politics, then about her own literary future: "[Y]et, I hope, the Reputation of my Pen is considerable enough to make his Glorious Name to survive to all Ages; with that of the Brave, the Beautiful, and the Constant Imoinda" $(O, 65)$. Describing the identification of and competition between author and heroine, Margaret Ferguson calls Behn's book "a safe-sex substitute for the potentially mutinous but also economically valuable black slavechild Oroonoko might have had with Imoinda." ${ }^{22}$ Whereas the English crown has failed to bind love and substitution together, the bond may be preserved - albeit uneasily - in the relationship between character and text, between heroine and author. Cultural upheaval gives rise to a literary changeling and a new occasion for female authorship. ${ }^{83}$

In imaginative literature, love proves compatible with economies of substitution. Oroonoko and Imoinda partly figure forth a number of personages-Adam and Eve, Aeneas and Dido, Charles I and Henrietta Maria, James II and Mary of Modena-yet future readers have confirmed the author's hope that this pair might retain enough singularity to produce a lasting impression of its own. Within the text, the love between Oroonoko and Imoinda preserves their identities. As Joseph M. Ortiz notes, Oroonoko's recognition of Imoinda restores her from her slave name, and Imoinda's loving gaze turns Caesar back into Oroonoko. ${ }^{84}$ Love and substitution occur not just between characters but between forms and genres as well. The mixed generic status of Oroonoko has been a source of sustained inquiry. The preponderance of substitution within the plot signals the text's filiation with romance, a genre that would remain a vehicle for political exchange during the upheavals of the seventeenth century. ${ }^{85}$ Critics have also placed Behn's work within the transition between the romance and the novel. ${ }^{86}$ Ortiz argues that Behn adapts a Virgilian mode of epic commemoration as she secures the "possibility of a novel, inscribed within an imperialist plot, that is specifically anti-imperialist." ${ }^{87}$ This claim relies partly on David Quint's account of the Virgilian epic of empire as a teleological narrative of imperial victory and romance dilation as a counterstrategy. ${ }^{88}$ Behn traces her epic pedigree not just to Virgilian but to Homeric origins, drawing strong parallels between Oroonoko and Achilles. At the end of the African romance episode, Oroonoko learns of Imoinda's fate and, in sorrow, refuses to participate in battle. Aboan plays the role of Patroclus until the hero sallies forth "out of his Pavillion . . . like some Divine Power descended to save his Country from Destruction" 
$(O, 29)$. Behn's reimagining of epic heroism hinges upon conjugal love: whereas Achilles burns with anger over the loss of his prize Briseis, Oroonoko laments the loss of his betrothed.

As a playwright, Behn emphasizes the role that drama plays in this literary family history. The opening pages of Oroonoko situate the narrative within an economy that includes the stage, as feathers from Surinam eventually become "the Dress of the Indian Queen" $(O, 9)$. Drama proves particularly suitable for thinking about substitution among characters. This reminds us that Milton's epic of married life had originally been conceived as the tragedy of Adam Unparadised, one of many tragedies that Milton tentatively planned. ${ }^{89}$ In 1671, the one tragedy Milton did complete would be attached to his brief epic. In Samson Agonistes, the impossibility of conjugal reconciliation at the heart of the tragedy becomes the grounds for Samson's final attack against his nation's oppressors. Whereas Paradise Regained concludes with Jesus's return to his mother's house, Milton's tragedy excises Samson's mother from the narrative and concludes with plans to return Samson's remains to his father's home as a monument to future generations. Samson is only a type of Christ, but his misogynistic heroism clarifies Jesus's situation by reducing familial relations to a line of fathers and sons.

Disruptions in patriarchal succession allowed Behn's female pen to compose Oroonoko not long before her death. In her final days, Behn declined to praise William III, but praised his wife Mary exuberantly in "A Congratulatory Poem to Her Sacred Majesty." ${ }^{\circ}$ Four years earlier, Behn had heralded this queen's father and stepmother in a Pindaric ode reminiscent of an epithalamion. "A Congratulatory Poem" finds a greater Mary who can be celebrated alone. "Maria with the Sun hath equal Force," Behn writes, and the poem confirms the pun between "sun" and "son." 91 Mary's "Lovely Face" reveals her "Father's Trace," and James's "God-like Attributes" are manifest in her mind. ${ }^{92}$ Behn finds herself able fully to express her Tory values in a poem of adoration for a royal woman. Behn's Mary is the subject and object of both love and substitution, the proper heir of a godlike father whose status as a wife seems hardly to matter at all.

Behn fulfills her own aspirations vicariously through Mary, for Behn herself longed to be a daughter and mother of literary history. In the aftermath of the Glorious Revolution, Behn becomes the encomiast of a new queen who can authorize her own desire to be irreplaceable both within and apart from the economy of marriage. It 
is ironic, though perhaps also fitting, that Behn's Oroonoko would be rewritten by the male playwright Thomas Southerne. Three centuries after Behn's Oroonoko, Biyi Bandele, a Nigerian playwright born in London, would adapt the novella again for the English stage. In 2008, this adaptation traveled from England to New York, the city for which the English had-foolishly, in Behn's eyes—-traded away Surinam. ${ }^{93}$ Despite being rewritten by male pens, and despite these temporal, generic, and geographical displacements, Behn's Oroonoko would eventually fulfill its author's hopes. Arising out of multiple economies of substitution, Oroonoko persists as a unique testament to the singularity of its female author.

\section{Swarthmore College}

\section{NOTES}

${ }^{1}$ James VI of Scotland, Basilikon Doron, Or His Majesties Instructions to His Dearest Sonne (London, 1603), 3.

${ }^{2}$ Ernst Kantorowicz, The King's Two Bodies: A Study in Mediaeval Political Theology (Princeton: Princeton Univ. Press, 1957), 21.

${ }^{3}$ Quoted in Kantorowicz, 223.

${ }^{4}$ Kantorowicz, 223. Michael J. Enright suggests the description of Christ as loving husband in Ephesians 5:22 as a model for James's rhetoric; see "King James and His Island: An Archaic Kingship Belief?," Scottish Historical Review 55 (1976): 29-40.

${ }^{5}$ Unless otherwise noted, biblical quotations refer to the 1611 Authorized Version.

${ }^{6}$ Early modern marriage has been a source of historical enquiry. Especially influential has been the work of Lawrence Stone, including The Crisis of the Aristocracy, 1558-1641 (Oxford: Oxford Univ. Press, 1965), The Family, Sex, and Marriage in England, 1500-1800 (New York: Harper \& Row, 1977), Road to Divorce: England, 1530-1987 (Oxford: Oxford Univ. Press, 1990), and Uncertain Unions: Marriage in England, 1660-1753 (Oxford: Oxford Univ. Press, 1992). Stone's claims against strong emotional bonds within early modern families have been controversial. "Much of what Prof. Stone has to say about the upper 10 per cent of the population is fascinating and convincing," writes Christopher Hill in his review of Sex, Marriage, and the Family in England (Economic History Review 31 [1978]: 457). Hill goes on to note, however, that "[f] or classes below that level it is difficult to find evidence" (457). For a thorough historical account of the experience of early modern marriage across social strata, see David Cressy, Birth, Marriage, and Death: Ritual, Religion, and the Life-Cycle in Tudor and Stuart England (Oxford: Oxford Univ. Press, 1997). For some influential accounts of John Milton's view of marriage, see David Aers and Bob Hodge, "Rational Burning": Milton on Sex and Marriage," Milton Studies 13 (1979): 3-33; James Grantham Turner, One Flesh: Paradisal Marriage and Sexual Relations in the Age of Milton (Oxford: Oxford Univ. Press, 1987); and Mary Nyquist, "The Genesis of Gendered Subjectivity in the Divorce Tracts and in Paradise Lost," in Re-membering Milton, ed. Nyquist and Margaret W. Ferguson (New York: Methuen, 1988), 99-127.

${ }^{7}$ Richard Kroll, "Tales of Love and Gallantry: The Politics of Oroonoko," Huntington Library Quarterly 67 (2004): 578. 
${ }^{8}$ Kroll participates in an extended debate about the significance of race and slavery in Oroonoko. In Ends of Empire: Women and Ideology in the Early-Eighteenth Century (Ithaca: Cornell Univ. Press, 1993), Laura Brown reminds us of Oroonoko's status as "a seminal work in the tradition of antislavery writings from the time of its publication down to our own period" (25), yet she also points out that according to the narrative "the trade in slaves is unjust only if and when slaves are not honorably conquered in battle" (47-48). Anita Pacheco examines how Behn's depiction of slavery primarily serves to articulate the author's royalist views and to lament attacks on hierarchical codes of honor; see "Royalism and Honor in Aphra Behn's Oroonoko," SEL: Studies in English Literature, 1500-1900 34 (1994): 491-506. Pacheco relies in part on George Guffey; see his "Aphra Behn's Oroonoko: Occasion and Accomplishment," in Two English Novelists: Aphra Behn and Anthony Trollope (Los Angeles: Univ. of California Press, 1975), 3-41.

${ }^{9}$ This essay can only gesture briefly toward a genealogical investigation that, if pursued at greater length, would offer a new history of literary trends leading to the bourgeois novel and its depictions of marriage. Michel Foucault explicitly invokes Kantorowicz's notion of the king's two bodies as he pursues his own genealogical project in Discipline and Punish: The Birth of the Prison, trans. Alan Sheridan, 2nd ed. (New York: Vintage, 1995), 29. The excavation of the specifically theological underpinnings of modern thought continues in the work of thinkers such as Giorgio Agamben; see especially Homo Sacer: Sovereign Power and Bare Life, trans. Daniel Heller-Roazen (Stanford: Stanford Univ. Press, 1998), and The Kingdom and the Glory: For a Theological Genealogy of Economy and Government, trans. Lorenzo Chiesa with Matteo Mandarini (Stanford: Stanford Univ. Press, 2011). In literary studies, scholars have produced insights about early modern literature by attending to matters of political theology. For some relevant examples, see Victoria Kahn, "Disappointed Nationalism: Milton in the Context of Seventeenth-Century Debates about the Nation-State," in Early Modern Nationalism and Milton's England, ed. David Loewenstein and Paul Stevens (Toronto: Univ. of Toronto Press, 2008), 249-72, and Wayward Contracts: The Crisis of Political Obligation in England, 1640-1674 (Princeton: Princeton Univ. Press, 2004); see also Julia Reinhard Lupton, Citizen-Saints: Shakespeare and Political Theology (Chicago: Univ. of Chicago Press, 2005).

${ }^{10}$ William Shakespeare, Richard II, in The Riverside Shakespeare, 2nd ed., ed. G. Blakemore Evans and J. J. M. Tobin (Boston: Houghton Mifflin, 1996), act 5, scene 1, lines 71-75. All references to other works by Shakespeare also refer to The Riverside Shakespeare.

${ }^{11}$ Shakespeare, Richard II, 1.2.12-13.

${ }^{12}$ Shakespeare, Richard II, 5.2.89-90.

${ }^{13}$ Shakespeare, Richard II, 5.4.136.

${ }^{14}$ Laura Lunger Knoppers, Historicizing Milton: Spectacle, Power, and Poetry in Restoration England (Athens: Univ. of Georgia Press, 1994), 32-33.

${ }^{15}$ John Milton, The Tenure of Kings and Magistrates, in The Complete Prose Works of John Milton, 8 vol., ed. Don M. Wolfe and others (New Haven: Yale Univ. Press, 1953-82), 3:229-30.

${ }^{16}$ Milton, Paradise Regained, in Complete Shorter Poems, ed. John Carey, 2nd rev. ed. (Harlow: Longman, 2007), book 4, lines 518-19. Hereafter cited parenthetically by book and line number and abbreviated $P R$.

${ }^{17}$ Milton, Paradise Lost, 2nd ed., ed. Alastair Fowler (Harlow: Longman, 1998), book 9 , lines 828-30. Hereafter cited parenthetically by book and line number and abbreviated PL. 
${ }^{18}$ Milton's endorsements of divorce and remarriage still leave considerable room for ambivalence about loving a second spouse. The sonnet "Methought I saw my late espoused saint" compares the return of his deceased wife to that of Alcestis. In Euripides's Alcestis, Admetus swears not to remarry, and his resolve is later tested by Hercules. Whether Milton's sonnet refers to his first wife, Mary Powell, or to his second wife, Katharine Woodcock, remains the topic of longstanding debate. Either prospectively or retrospectively, however, the sonnet serves as evidence for the emotional complexities involved in remarriage.

${ }^{19}$ Milton, The Doctrine and Discipline of Divorce, in Complete Prose Works, 2:229. As Aers and Hodge point out that, properly speaking, Milton's analogy should compare the wife, not the husband, to the victim of ill government. This logical slippage takes part in Milton's uneasy maintenance of masculine superiority within companionate marriage and mutual love.

${ }^{20}$ Milton, Eikonklastes, in Complete Prose Works, 3:421.

${ }^{21}$ Milton, Doctrine and Discipline, 2:251.

${ }^{22}$ John Rogers, "Transported Touch: The Fruit of Marriage in Paradise Lost," in Milton and Gender, ed. Catherine Gimelli Martin (Cambridge: Cambridge Univ. Press, 2004), 125.

${ }^{23}$ Milton, Tetrachordon, in Complete Prose Works, 2:603.

${ }^{24}$ See Anthony Low, The Reinvention of Love: Poetry, Politics, and Culture from Sidney to Milton (Cambridge: Cambridge Univ. Press, 1993), 163-69.

${ }^{25}$ William Kerrigan, The Sacred Complex: On the Psychogenesis of Paradise Lost (Cambridge: Harvard Univ. Press, 1983), 102.

${ }^{26}$ Anselm of Canterbury, Why God Became Man, in The Major Works, ed. Brian Davies and G. R. Evans (Oxford: Oxford Univ. Press, 1998), 282.

${ }^{27}$ See Anselm, 283.

${ }^{28}$ Jaroslav Pelikan, The Christian Tradition: A History of the Development of Doctrine, 5 vol. (Chicago: Univ. of Chicago Press, 1984), 4:150.

${ }^{29}$ John Calvin, Institutes of the Christian Religion: 1536 Edition, trans. Ford Lewis Battles (Grand Rapids: Eerdmans, 1995), 55.

${ }^{30}$ See The Racovian Catechisme, trans. John Biddle(?) (Amsterdam, 1652), 122-26.

${ }^{31}$ See C. A. Patrides, "Milton and the Protestant Theory of the Atonement," PMLA 74 (1959): 7-13, esp. 7. See also Patrides, Milton and the Christian Tradition (Oxford: Clarendon, 1966), 153-219.

${ }^{32}$ John Donne, The Complete English Poems, ed. C. A. Patrides (New York: Everyman, 1991), line 1.

${ }^{33}$ See John P. Rumrich, "Milton's Arianism: Why It Matters," in Milton and Heresy, ed. Stephen B. Dobranski and Rumrich (Cambridge: Cambridge Univ. Press, 1998), 75-92. For arguments that Milton either ascribes to or accommodates antitrinitarian views, see Barbara Kiefer Lewalski, Milton's Brief Epic: The Genre, Meaning, and Art of Paradise Regained (Providence: Brown Univ. Press, 1966), esp. 138-48; and Michael Lieb, "Milton and the Socinian Heresy," in Milton and the Grounds of Contention, ed. Mark Kelley, Lieb, and John T. Shawcross (Pittsburgh: Duquesne Univ. Press, 2003), 234-83. Defenses of Milton's orthodoxy include Patrides, Christian Tradition; Dennis Danielson, Milton's Good God: A Study in Literary Theodicy (Cambridge: Cambridge Univ. Press, 1982); and William B. Hunter, Jr., "Milton's Arianism Reconsidered," Harvard Theological Review 53 (1959): 9-35, and "The Provenance of the Christian Doctrine," SEL: Studies in English Literature, 1500-1900 32 (1992): 129-42. 
${ }^{34}$ In Literature and the Politics of Family in Seventeenth-Century England (Cambridge: Cambridge Univ. Press, 2007), Su Fang Ng describes how Milton "undermines the authority of elder brothers and of fathers" and "disrupts family order, advancing instead a political state where merit and youth rather than age and authority prevail" (160).

${ }^{35}$ Richard Strier, "Milton Against Humility," in Religion and Culture in Renaissance England, ed. Claire McEachern and Debora Shuger (Cambridge: Cambridge Univ. Press, 1997), 275.

${ }^{36}$ See Thomas H. Luxon, Single Imperfection: Milton, Marriage, and Friendship (Pittsburgh: Duquesne Univ. Press, 2005), esp. 95-156.

${ }^{37}$ See Leah Whittington, "Vergil's Nisus and the Language of Self-Sacrifice in Paradise Lost," Modern Philology 107 (2010): 588-606. Whittington points out that early editors of Paradise Lost such as Thomas Newton have remarked upon the allusion to the Nisus and Euryalus episode. For a very different reading of this allusion and a claim that Milton's model of the atonement proves compatible with heroic friendship, see Gregory Chaplin, "Beyond Sacrifice: Milton and the Atonement," PMLA 125 (2010): 354-69.

${ }^{38}$ Virgil, Aeneid, trans. H. R. Fairclough, rev. G. P. Goold, Loeb Classical Library (Cambridge: Harvard Univ. Press, 2001), book 9, lines 427-29.

${ }^{39}$ See Patrides, "Atonement," 8.

${ }^{40}$ As critics have shown, Milton's monistic vitalism supports-albeit in complicated ways-his antimonarchical, republican politics. See, for example, Rogers, The Matter of Revolution: Science, Poetry, and Politics in the Age of Milton (Ithaca: Cornell Univ. Press, 1996), 103-76; and Rachel J. Trubowitz, "Body Politics in Paradise Lost," PMLA 121 (2006): 388-404.

${ }^{41}$ See Lewalski, Paradise Lost and the Rhetoric of Literary Forms (Princeton: Princeton Univ. Press, 1985), 214. Clay Daniel argues that Raphael's Neoplatonism should be read as problematic and as a potential source of error for Adam; see "Milton's Neo-Platonic Angel?” SEL: Studies in English Literature, 1500-1900 44 (2004): 173-88. My argument suggests a different reason for why Raphael's vision of the universe contradicts Adam's lived experience.

${ }^{42}$ See Richard C. McCoy, Alterations of State: Sacred Kingship in the English Reformation (New York: Columbia Univ. Press, 2002), 87-121.

${ }^{43}$ Regina Mara Schwartz, Sacramental Poetics at the Dawn of Secularism: When God Left the World (Stanford: Stanford Univ. Press, 2008), 64. See also Denise Gigante, Taste: A Literary History (New Haven: Yale Univ. Press, 2005), esp. 22-46.

${ }^{44}$ See Schwartz, 76.

${ }^{45}$ For an extended analysis of Milton's views on forensic atonement and penal substitution, both in De Doctrina Christiana and in his poetry, see Russell M. Hillier, Milton's Messiah: The Son of God in the Works of John Milton (Oxford: Oxford Univ. Press, 2011), esp. 9-36.

${ }^{46}$ Janel Mueller argues that while dominion persists in the gendered hierarchy of marriage, the Son's relationship with his mother represents a domesticity without dominion; see "Dominion as Domesticity: Milton's Imperial God and the Experience of History," in Milton and the Imperial Vision, ed. Balachandra Rajan and Elizabeth Sauer (Pittsburgh: Duquesne Univ. Press, 1999), 25-47.

${ }^{47}$ The precise meaning of the climactic temple scene and its implications for our understanding of Milton's theology either as Trinitarian or as antitrinitarian have been the subject of intense scrutiny. Louis Martz is among the critics who argue that the Son manifests his divine identity in this scene; see Poet of Exile: A Study of Milton's Poetry 
(New Haven: Yale Univ. Press, 1980), 254. Lewalski, by contrast, suggests that Jesus's miracle is performed by the Father's power; see Brief Epic, 316. For the claim that Jesus's act is fully human, see Ashraf H. A. Rushdy, "Standing Alone on the Pinnacle: Milton in 1752," Milton Studies 26 (1990): 193-218.

${ }^{48}$ Especially since Lewalski's Milton's Brief Epic, readers have recognized the Book of Job as a model for Paradise Regained. Recently, Kahn has focused on the ways in which Jesus's Joblike irony raises questions about the salvation narrative; see "Job's Complaint in Paradise Regained," ELH 76 (2009): 625-60,

${ }^{49}$ George Abbot, The Whole Book of Job Paraphrased (London, 1640), 270.

${ }^{50}$ Abbot, 271.

${ }^{51}$ See Calvin, Sermons of Master Iohn Caluin, upon the Booke of Job, trans. Arthur Golding (London: 1574), 11.

${ }^{52}$ Calvin, Sermons, 820.

${ }^{53}$ Aphra Behn, Oroonoko, ed. Joanna Lipking (New York: Norton, 1997), 15. Hereafter cited parenthetically by page number and abbreviated $O$.

${ }^{54}$ Behn, The Forc'd Marriage; or The Jealous Bridegroom, in The Works of Aphra Behn, 7 vol., ed. Janet Todd (Columbus: Ohio State Univ. Press, 1992-96), 5:53; act 4 , scene 2 , line 39.

${ }_{55}^{5}$ Behn, The Forc'd Marriage, 4.7.36-42.

${ }^{56}$ Todd, The Secret Life of Aphra Behn (New Brunswick: Rutgers Univ. Press, 1997), 140.

${ }^{57}$ Behn, "Pindarick Poem on the Coronation," in Works, 1:202, line 84.

${ }^{58}$ Behn, "Pindarick," lines 106, 134-35.

${ }^{59}$ Behn, "Pindarick," lines 534, 548-50.

${ }^{60}$ The Capuchin Lawrence of Brindisi does so by citing the authority of Epiphanius, Rupert of Salzburg, and Bernard of Clairvaux. See Saint Lawrence of Brindisi, "On the Excellence of the Virgin Mother of God," in The Mariale, trans. Vernon P. Wagner (Delhi: Media House, 2007), 32-33.

${ }^{61}$ The Bible and Holy Scriptures Conteyned in the Olde and Newe Testament (London, 1579), Rev. 12:6n.

${ }^{62}$ See Kroll, “Tales," 581.

${ }^{63}$ Pacheco, 499-500.

${ }^{64}$ Lois Potter, "The Royal Martyr in the Restoration," in The Royal Image: Representations of Charles I, ed. Thomas N. Corns (Cambridge: Cambridge Univ. Press, 1999), 251. Potter discusses the parallels between the frontispieces depicting Charles I and James II in Eikon Basilike and Imago Regis (1692), respectively; see 257-58. Even as the latter book imitates the former in aligning James with Christ, its frontispiece cannot present James mimicking Charles mimicking Christ. Potter concludes that the obsolete figure of the martyr is replaced by that of the patriot.

${ }^{65}$ Knoppers, "Reviving the Martyr King: Charles I as Jacobite icon," in The Royal Image, 270.

${ }^{66}$ In Sick Economies: Drama, Mercantilism, and Disease in Shakespeare's England (Philadelphia: Univ. of Pennsylvania Press, 2004), Jonathan Gil Harris argues that mercantilism generates a discursive field around sovereign power and exchange that deploys the trope of domestic and foreign bodies. Drawing partly upon Harris's work, Zachary Lesser attends specifically to the genre of Jacobean tragicomedy as a way of representing international exchange (which depends on factors such as exchange rates beyond a monarch's power) within a conservative framework of authority; see "Tragical-Comical-Pastoral-Colonial: Economic Sovereignty, Globalization, and the Form of Tragicomedy," ELH 74 (2007): 881-908, 
${ }^{67}$ See Kroll, Restoration Drama and "The Circle of Commerce": Tragicomedy, Politics, and Trade in the Seventeenth Century (Cambridge: Cambridge Univ. Press, 2007).

${ }^{68}$ Stephanie Athey and Daniel Cooper Alarcón, "Oroonoko's Gendered Economies of Honor/Horror: Reframing Colonial Discourse Studies in the Americas," in Subjects and Citizens: Race and Gender from Oroonoko to Anita Hill, ed. Cathy N. Davidson (Durham: Duke Univ. Press, 1995), 37-38.

${ }^{69}$ Charlotte Sussman describes Imoinda's body as the victim of two forces: a "crisis in property relations" that would make her royal offspring chattel, and her potency as a virtuous and alluring romance heroine ("The Other Problem with Women: Reproduction and Slave Culture in Aphra Behn's Oroonoko," in Rereading Aphra Behn: History, Theory, and Criticism, ed. Heidi Hutner [Charlottesville: Univ. of Virginia Press, 1993], 216-17).

${ }^{70}$ Shakespeare, Measure for Measure, 5.1.409.

${ }^{71}$ Shakespeare, Measure for Measure, 5.1.426.

${ }^{72}$ Shakespeare, Othello, 2.1.292-94.

${ }^{73}$ Shakespeare, Othello, 2.1.299.

${ }^{74}$ Shakespeare, Othello, 5.2.347-48. For the textual variant in the First Folio, see Riverside Shakespeare, line 1296, note 347.

${ }^{75}$ I thank Katharine Eisaman Maus for this observation.

${ }^{76}$ John Maxwell, Sacro-sancta Regum Majestas: Or the Sacred and Royal Prerogative of Christian Kings (London, 1680), 257.

${ }^{77}$ Nath.[aniel] Bisbie, Two Sermons. The First Shewing the Mischiefs of Anarchie. The Second, the Mischiefs of Sedition (London, 1684), 4.

${ }^{78}$ William Denton, Jus Regiminis: Being a Justification of Defensive Arms in General and Consequently of Our Late Revolutions (London, 1689), 50.

${ }^{79}$ Elliott Visconsi shows that Behn's chief concern is the domestic form of barbarism produced by cultural debasement; see "A Degenerate Race: English Barbarism in Aphra Behn's Oroonoko and The Widow Ranter," ELH 69 (2002): 673-701.

${ }^{80}$ Ian Watt, The Rise of the Novel: Studies in Defoe, Richardson, and Fielding, 2nd Am. ed. (Berkeley: Univ. of California Press, 2001), 137.

${ }^{81}$ See Michael McKeon, The Origins of the English Novel, 1600-1740, 2nd ed. (Baltimore: Johns Hopkins Univ. Press, 2002), esp. 1-24. In a new introduction to this edition, McKeon defends his dialectical method against charges of teleological thinking. Whereas romance idealism gives way to empiricism and then to skepticism, reflecting shifts from aristocratic to conservative to progressive values, McKeon maintains that "the novel is constituted by the simultaneous interplay of these several categories, none of which possess a chronological priority or finality" (xviii).

${ }^{82}$ Ferguson, "Juggling the Categories of Race, Class, and Gender: Aphra Behn's Oroonoko," in Women, "Race," and Writing in the Early Modern Period, ed. Margo Hendricks and Patricia Parker (London: Routledge, 1994), 222. It may be accurate to refer to the book as a safe race substitute; the female writer's status as a Christian and European that allows her to be an economic agent, whereas Imoinda is doomed to be an object.

${ }^{83}$ Oroonoko's fictionalized biography of the author suggests that she wields her female pen only because of a chain of failed substitutions. Behn stays in Surinam only because her father, the "Lieutenant-General of Six and thirty Islands" dies at sea $(O, 43)$. Behn relates the conditions of her authorship to the loss of Surinam, for she claims to write only because the Dutch have killed and banished others who could have written of Oroonoko. The author is, in fact, a replacement for the deceased Trefry. 
${ }^{84}$ See Joseph M. Ortiz, "Arms and the Woman: Narrative, Imperialism, and Virgilian Memoria in Aphra Behn's Oroonoko," Studies in the Novel 34 (2002): 119-40, esp. 128-29.

${ }^{85}$ See, for example, Annabel Patterson, Censorship and Interpretation: The Conditions of Writing and Reading in Early Modern England (Madison: Univ. of Wisconsin Press, 1984); Potter, Secret Rites and Secret Writing: Royalist Literature, 1641-1660 (Cambridge: Cambridge Univ. Press, 1989); and Kahn, Wayward Contracts: The Crisis of Political Obligation in England, 1640-1674 (Princeton: Princeton Univ. Press, 2004), esp. 177-251.

${ }^{86}$ Firdous Azim's The Colonial Rise of the Novel (London: Routledge, 1993) explores the ideological questions about racial and gendered individualism that attend transitional status between romance and early novel; see 34-60. See also Oddvar Holmesland, "Aphra Behn's Oroonoko: Cultural Dialectics and the Novel," ELH 68 (2001): 57-79.

${ }^{87}$ Ortiz, 120.

${ }^{88}$ See David Quint, Epic and Empire: Politics and Generic Form from Virgil to Milton (Princeton: Princeton Univ. Press, 1993).

${ }^{89}$ For a transcription of the relevant portions of the Trinity manuscript, see David Masson, The Life of John Milton, 7 vol. (Cambridge: Macmillan, 1871), 2:106-15.

${ }^{90}$ Behn did compose a Pindaric ode for William's supporter Gilbert Burnet. For the politically ambiguous message of this ode, see Todd, 424-28.

${ }^{91}$ Behn, "A Congratulatory Poem," in Works, 1:305, line 45.

${ }^{92}$ Behn, "A Congratulatory Poem," lines 89-90, 95.

${ }^{93}$ See Elizabeth Kowaleski Wallace, "Transnationalism and Performance in 'Biyi Bandele’s Oroonoko," PMLA 112 (2004): 265-81. 